\title{
1-Butyl-3-methylimidazolium Hexafluorophosphate Ionic Liquid as a New Solvent for the Determination of Lead(II) and Cadmium(II) by Anodic Stripping Voltammetry after Extraction of the Iodide Complexes
}

\author{
Akihiro KAMIO and Yukio NAGAOSA ${ }^{\dagger}$ \\ Department of Applied Chemistry and Biotechnology, Graduate School of Engineering, \\ University of Fukui, Bunkyo, Fukui 910-8507, Japan
}

\begin{abstract}
The use of 1-butyl-3-methylimidazolium hexafluorophosphate $\left(\mathrm{BMIM} \cdot \mathrm{PF}_{6}\right)$ as a solvent for the anodic stripping analysis of $\mathrm{Pb}$ (II) and $\mathrm{Cd}(\mathrm{II})$ after extraction of the iodide complexes has been investigated. This method is based on the extraction of the metal iodide complexes into BMIM $\cdot \mathrm{PF}_{6}$, followed by differential-pulse anodic stripping voltammetry with an in-situ plated bismuth film electrode onto an edge-plane type of pyrolytic graphite substrate. When tetra- $n$-propylammonium iodide at a concentration of $0.20 \mathrm{~mol} \mathrm{~L}^{-1}$ was used as an extractant and a supporting electrolyte, the reduced lead and cadmium produced well-defined anodic peaks at -414 and $-736 \mathrm{mV} v s$. $\mathrm{Ag} / \mathrm{AgCl}$, respectively. The peak currents for $\mathrm{Pb}$ (II) and $\mathrm{Cd}(\mathrm{II})$ were directly proportional to the initial metal concentration in the ranges of $0.01-0.50 \mu \mathrm{g} \mathrm{mL} \mathrm{m}^{-1}$ and $0.05-1.0 \mu \mathrm{g} \mathrm{mL} \mathrm{m}^{-1}$ under the optimized conditions. A detection limit $(S / N=3)$ of $0.001 \mu \mathrm{g} \mathrm{mL}^{-1} \mathrm{~Pb}(\mathrm{II})$ was obtained with a volume ratio $\left(V_{\mathrm{aq}} / V_{\mathrm{BMIM} \cdot \mathrm{PF}_{6}}\right)$ of 2.0 at $300 \mathrm{~s}$ deposition time. The relative standard deviation was $3.2 \%$ on replicate runs $(n=10)$ for the determinations of $0.20 \mu \mathrm{g} \mathrm{mL}^{-1} \mathrm{~Pb}(\mathrm{II})$.
\end{abstract}

(Received March 31, 2008; Accepted May 29, 2008; Published October 10, 2008)

\section{Introduction}

Numerous stripping voltammetric techniques have been reported for determination of trace metals and biologically important constituents in environmental and biological samples. ${ }^{1,2}$ These methods, in most cases, are very sensitive and satisfactory enough to achieve the determination of target species at trace levels in a variety of samples when mercury-based electrodes such as the film and hanging drop electrodes are used. ${ }^{3-7}$ Because mercury is very toxic in living organisms and is a hazardous pollutant, the metal electrodes should be replaced by such anodically stable metals as Au-,${ }^{8-10} \mathrm{Pt}-,{ }^{11}$ or carbon-based electrodes. ${ }^{12,13}$ Recently, the environmentally friendly bismuthfilm electrode has attracted increasing attention in anodic stripping analysis of $\mathrm{Pb}, \mathrm{Cd}, \mathrm{Zn}, \mathrm{Tl}, \mathrm{Sn}, \mathrm{As}$, Se and adsorptive stripping analysis of $\mathrm{Ni}, \mathrm{Co}, \mathrm{U}^{14-24}$ On the other hand, voltammetric analysis in non-aqueous media has been carried out after liquid-liquid extractions with a range of organic solvents to overcome difficulties in selectivity that were often caused in aqueous media. We previously developed several voltammetric methods combined with liquid-liquid extractions with non-aqueous solvents such as acetonitrile, propylene carbonate, or dichloromethane..$^{25-28}$ In the future, the use of volatile and water-soluble organic solvents as well as toxic metal electrodes may become seriously restricted and therefore should be avoided from the standpoints of environmental protection and human health.

Room-temperature ionic liquids have been recognized to be excellent and new solvents, and have been intensively studied in

† To whom correspondence should be addressed.

E-mail: nagaosa@acbio2.acbio.fukui-u.ac.jp research fields of electroanalytical applications as well as in separation sciences such as solvent extraction and chromatography. ${ }^{29-35}$ This is due to their unique physicochemical properties such as negligible vapor pressure, high ionic conductivity, and fairly good solubilities of organic and inorganic compounds. More recently, Jia et al. have studied the use of 1-butyl-3-methylimidazolium hexafluorophosphate $\left(\mathrm{BMIM} \cdot \mathrm{PF}_{6}\right)$ in solid matrices of the bismuth film electrodes. ${ }^{36}$ In this study, we devoted much attention to developments of analytical applications of room-temperature ionic liquids as the solvents for both stripping voltammetry and solvent extraction. Among ionic liquids commonly used, 1-butyl-3methylimidazolium-based liquids of various counter anions were firstly investigated to extract some metal (e.g. lead and cadmium) complexes with iodide and then to make direct voltammetric measurements in ionic-liquid (non-aqueous) phases. The relatively high viscosity of room-temperature ionic liquids is expected to lower the voltammetric responses of redox reactions on the electrodes, due to considerably smaller diffusion coefficients of solutes. ${ }^{37}$ However, it is thought valuable to make an attempt to show that anodic stripping measurements are feasible in such ionic liquids, after the metal iodide complexes are extracted by purging nitrogen through the two immiscible liquid phases.

In the present research, 1-butyl-3-methylimidazolium hexafluorophosphate $\left(\mathrm{BMIM} \cdot \mathrm{PF}_{6}\right)$ was proposed as an ionic liquid (non-aqueous solvent) to extract the $\mathrm{Pb}$ (II) and $\mathrm{Cd}(\mathrm{II})$ iodide complexes by adding tetra- $n$-propylammonium iodide (TPAI), enabling direct measurements of differential-pulse anodic stripping voltammetry (DPASV) for the determination of the two metals. Bismuth(III) was also extracted into the $\mathrm{BMIM} \cdot \mathrm{PF}_{6}$ phase, followed by formation of an in-situ bismuthfilm electrode when the potential was applied to an edge-plane 
pyrolitic graphite substrate at $-1100 \mathrm{mV}$ vs. $\mathrm{Ag} / \mathrm{AgCl}$. Bismuthbased electrodes have been used as suitable alternatives to mercury-based electrodes due to environmental friendliness and very low toxicity. The aim of this study is to investigate as to whether $\mathrm{BMIM} \cdot \mathrm{PF}_{6}$ is usable for liquid-liquid extraction followed by DPASV. Here, we describe how the metal iodide complexes were extracted via formation of micro-emulsion of the two immiscible liquids by nitrogen purge, allowing anodic stripping voltammetric determination of $\mathrm{Pb}$ (II) and $\mathrm{Cd}(\mathrm{II})$ at $\mu \mathrm{g} \mathrm{L}^{-1}$ concentration levels.

\section{Experimental}

\section{Apparatus}

A Cypress System Model CS-1200 voltammetric analyzer (Cypress Systems, MA) was employed for electrochemical measurements of cyclic and differential-pulse voltammetry. Unless otherwise stated, the settings for differential-pulse voltammetry were as follows: $2 \mathrm{mV}$ step height; $50 \mathrm{mV}$ pulse amplitude; pulse period of time, $20 \mathrm{~ms} ; 10 \mathrm{~s}$ rest period after deposition. An edge-plane pyrolytic graphite disk $(3.0 \mathrm{~mm}$ diameter, BAS) was used as working electrode substrate, a platinum wire was used as counter electrode and an $\mathrm{Ag} / \mathrm{AgCl}$ (sat. $\mathrm{KCl}$ ) reference electrode was used.

\section{Reagents and solutions}

All solutions were prepared with deionized and distilled water. $\mathrm{BMIM} \cdot \mathrm{PF}_{6}$ and the other reagents used in this study were from Wako Pure Chemical Industries Co Ltd. (Tokyo, Japan). The Pb(II) and Cd(II) solutions were prepared by diluting the $1000 \mu \mathrm{g} \mathrm{mL}^{-1}$ metal ion standards (for atomic absorption spectrometry) with $0.01 \mathrm{~mol} \mathrm{~L}^{-1}$ hydrochloric acid. The stock $\mathrm{Bi}(\mathrm{III})$ solution was prepared by dissolving $\mathrm{Bi}\left(\mathrm{NO}_{3}\right)_{2}$ in $0.5 \mathrm{~mol} \mathrm{~L}^{-1}$ nitric acid. The foreign metal ion solutions were prepared by diluting their metal ion standards $\left(1000 \mu \mathrm{g} \mathrm{mL}^{-1}\right)$ with $0.1 \mathrm{~mol} \mathrm{~L}^{-1}$ hydrochloric acid. All stock solutions were stored in a refrigerator at $2^{\circ} \mathrm{C}$.

\section{Preparation of the working electrode}

Prior to electrochemical measurement, the edge-plane graphite electrode was cleaned daily by polishing with aluminum oxide slurry and next with a piece of Nuclepore filter paper. The treated electrode was then immersed in $1.0 \mathrm{~mol} \mathrm{~L}^{-1}$ hydrochloric acid for $1 \mathrm{~min}$, and rinsed with water. After voltammetric measurements, the working electrode was treated as described above, and reactivated each time by keeping the electrode potential at $800 \mathrm{mV}$ for $30 \mathrm{~s}$.

Procedure for differential-pulse voltammetric determination of $\mathrm{Pb}(I I)$ and $C d(I I)$

The standard procedure for the determination of $\mathrm{Pb}(\mathrm{II})$ and $\mathrm{Cd}(\mathrm{II})$ by the proposed method was set as follows: an aliquot (less than $1.0 \mathrm{~mL}$ ) of standard $\mathrm{Pb}$ (II) and $\mathrm{Cd}(\mathrm{II})$ solution was placed into a 5.0-mL electrolytic glass cell. $\mathrm{Bi}(\mathrm{III})$ standard solution $\left(100 \mu \mathrm{g} \mathrm{mL}^{-1}\right), 1.0 \mathrm{~mol} \mathrm{~L}^{-1}$ sodium acetate buffer $(\mathrm{pH}$ 4.5) and $2.0 \mathrm{~mol} \mathrm{~L}^{-1}$ potassium nitrate were successively added to the sample solution. The total volume was finally made up to $2.0 \mathrm{~mL}$ with water. The equilibrium concentrations except for the two metal ions were adjusted to $5.0 \mu \mathrm{g} \mathrm{mL} \mathrm{m}^{-1} \mathrm{Bi}(\mathrm{III}), 0.1 \mathrm{~mol}$ $\mathrm{L}^{-1}$ acetate buffer $\left(\mathrm{pH} 4.5\right.$ ) and $0.5 \mathrm{~mol} \mathrm{~L}^{-1}$ potassium nitrate. Two milliliters of $0.20 \mathrm{~mol} \mathrm{~L}-1$ TPAI solution in BMIM.PF were added, and nitrogen was then purged into the two liquid phases for $300 \mathrm{~s}$ in order to extract the metal iodide complexes into the BMIM.PF 6 phase. The extracted $\mathrm{Pb}(\mathrm{II})$ and $\mathrm{Cd}(\mathrm{II})$ was initially reduced at a potential of $-1100 \mathrm{mV}$ for $180 \mathrm{~s}$ in a stirred
$\mathrm{BMIM} \cdot \mathrm{PF}_{6}$ phase. After a 10-s rest period, DPASV measurements were performed by scanning the potentials from -1100 to $0 \mathrm{mV}$ in the positive direction.

\section{Results and Discussion}

Preliminary investigations for selection of ionic liquid and extractant used in this study

Several ionic liquids as solvents were tested for direct DPASV measurements after the extraction of the $\mathrm{Pb}$ (II) and $\mathrm{Cd}$ (II) iodide complexes. Our previous studies revealed that the metal iodide complexes could easily be extracted as their ion-association compounds with hydrophobic quarternary ammonium cations into relatively polar organic solvents such as chloroform, dichlomethane, propylene carbonate and salted-out acetonitrile. ${ }^{25-28}$ In this study, the ion-pair extraction can be performed with 1-butyl-3methylimidazolium hexafluorophosphate and its tetrafluoroborate ionic liquids, because they could extract the metal iodide complexes from aqueous solutions by the addition of several tetra- $n$-alkylammonium salts. 1-Butyl-3-methylimidazolium tetrafluoroborate, however, was fairly water-miscible (hydrophilic) and therefore is considered unsuitable for the DPASV determination of the two metal ions. Bis(trifluoromethylsulfonyl)imide salts of the imidazolium and some alkylpyridinium cations are water-immiscible and have lower viscocities, but the anodic stripping currents for $\mathrm{Pb}(\mathrm{II})$ and $\mathrm{Cd}(\mathrm{II})$ were about onefifth those obtained by BMIM.PF ${ }_{6}$. This is probably because the hydrophobic anion interfered with the extraction of the $\mathrm{Pb}$ (II) and $\mathrm{Cd}(\mathrm{II})$ complexes into the ionic liquids investigated. $\mathrm{BMIM} \cdot \mathrm{PF}_{6}$ was therefore selected for use as the ionic liquid for the extraction of the metal complexes, followed by direct DPASV measurements.

Tetra- $n$-alkylammonium (from $\mathrm{C}_{2}$ to $\mathrm{C}_{6}$ ) iodide salts were tested as both extractants of the metal iodide complexes and supporting electrolytes which were dissolved in $\mathrm{BMIM} \cdot \mathrm{PF}_{6}$ before extraction. TPAI gave the highest peak currents of $\mathrm{Pb}(\mathrm{II})$ and $\mathrm{Cd}(\mathrm{II})$ when the standard procedures were conducted. The second highest current was obtained with tetra- $n$ butylammonium iodide, which was also found to be usable in this study. The peak potentials shifted to negative values as the chain length of the tetra- $n$-alkylammonium cations increased.

\section{DPASV for $P b(I I)$ and $C d(I I)$ complexes extracted into BMIM.PF 6 phase}

It was found that $\mathrm{Pb}$ (II) and $\mathrm{Cd}(\mathrm{II})$ could be extracted into the $\mathrm{BMIM} \cdot \mathrm{PF}_{6}$ phase containing $0.20 \mathrm{~mol} \mathrm{~L}{ }^{-1} \mathrm{TPAI}$ and gave welldefined DPASV responses that were suited for the determination of the two metals. Figure 1 shows typical DPASV curves obtained for the blank test (A): BMIM.PF $F_{6}$ phase $\left(0.20 \mathrm{~mol} \mathrm{~L}{ }^{-1}\right.$ TPAI) after extraction without the target metal ions (curve 1); an aqueous test solution (B): an aqueous sample solution $(0.1 \mathrm{~mol}$ $\mathrm{L}^{-1}$ sodium acetate buffer, $\left.\mathrm{pH} 4.5\right)$ containing $0.5 \mu \mathrm{g} \mathrm{mL}^{-1}$ each $\mathrm{Pb}$ (II) and $\mathrm{Cd}(\mathrm{II})$, and $5.0 \mu \mathrm{g} \mathrm{mL}^{-1} \mathrm{Bi}$ (III) (curve 2); test solution (C): BMIM $\cdot \mathrm{PF}_{6}$ phase after the nitrogen-purge through the two liquid phases comprising (A) and (B) at the volume ratio of 1:1 (curve 3). It can be seen from Fig. 1 curve 3 that well-defined DPASV peaks for $\mathrm{Cd}(\mathrm{II}), \mathrm{Pb}(\mathrm{II})$ and $\mathrm{Bi}(\mathrm{III})$ were obtained at $-736,-414$ and $-110 \mathrm{mV}$ vs. $\mathrm{Ag} / \mathrm{AgCl}$, respectively. The linear relationships between $I_{\mathrm{p}}$ and $v^{1 / 2}$ in cyclic voltammetry indicate that the anodic stripping peaks were diffusion-controlled. The peak current for $\mathrm{Pb}$ (II) shown in Fig. 1 curve 3 was much larger than expected from the rather high viscosity of BMIM.PF $(272 \mathrm{mPa}$, at $278 \mathrm{~K}),{ }^{31}$ and was comparable to that obtained in aqueous samples (Fig. 1 curve 2). Due to the decreased 


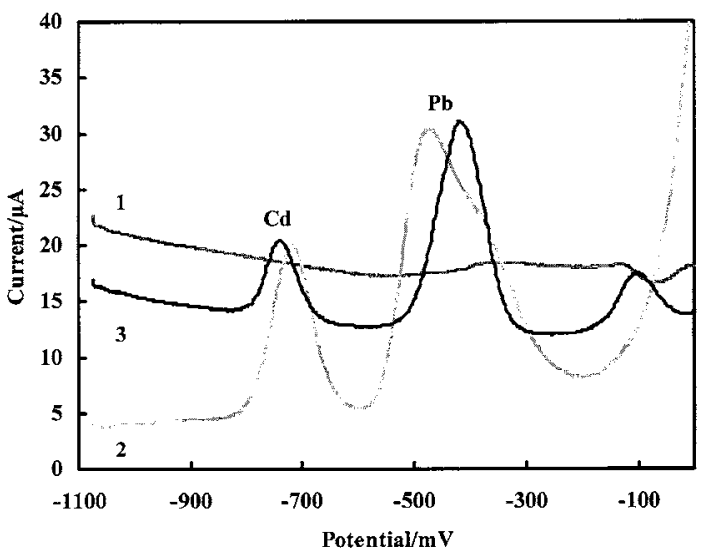

Fig. 1 DPASV curves obtained for the metal iodide complexes. 1, $0.20 \mathrm{~mol} \mathrm{~L}{ }^{-1}$ TPAI solution in BMIM.PF $\mathrm{F}_{6}$ after extraction equilibrium with aqueous solution containing $0.1 \mathrm{~mol} \mathrm{~L}^{-1}$ acetate buffer $(\mathrm{pH} 4.5)$ and $0.5 \mathrm{~mol} \mathrm{~L}^{-1}$ potassium nitrate; 2 , a mixed solution of $0.1 \mathrm{~mol} \mathrm{~L}^{-1}$ acetate buffer $(\mathrm{pH} 4.5)$ and $0.5 \mathrm{~mol} \mathrm{~L}^{-1}$ potassium nitrate containing $0.5 \mu \mathrm{g} \mathrm{mL}^{-1} \mathrm{~Pb}(\mathrm{II}), 0.5 \mu \mathrm{g} \mathrm{mL} \mathrm{m}^{-1} \mathrm{Cd}(\mathrm{II})$ and $5.0 \mu \mathrm{g} \mathrm{mL}{ }^{-1} \mathrm{Bi}(\mathrm{III}) ; 3$, $0.20 \mathrm{~mol} \mathrm{~L}^{-1} \mathrm{TPAI}$ solution in BMIM.PF${ }_{6}$ after extraction equilibrium with the mixed solution containing 1 and 2 at the volume ratio of $1: 1$; nitrogen purge time, $300 \mathrm{~s}$; deposition potential, $-1100 \mathrm{mV}$ deposition time, $180 \mathrm{~s}$; scan rate, $100 \mathrm{mV} \mathrm{s}^{-1}$.

extractability, on the other hand, the Cd(II) peak current exhibited about a half of the value compared to that shown in Fig. 1 curve 2, but doubled when $1.0 \mathrm{~mol} \mathrm{~L}^{-1}$ potassium nitrate was added. The proposed method using BMIM $\cdot \mathrm{PF}_{6}$ ionic liquid would improve the apparent sensitivity by increasing the volume ratio of $V_{\text {aq }} / V_{\text {BMIM.PF}_{6}}$ and the selectivity from some interfering ions that coexisted. A small anodic peak due to iodine formation appeared at around $-400 \mathrm{mV}$, as shown in Fig. 1 curve 1 , and showed a slight interference when the $\mathrm{Pb}$ (II) peak current was estimated at the lower concentrations. It is clear from Fig. 1 curve 2 that the distorted anodic peak for $\mathrm{Pb}$ (II) was observed in $0.10 \mathrm{~mol} \mathrm{~L}^{-1}$ sodium acetate buffer ( $\left.\mathrm{pH} 4.5\right)$ when $5.0 \mu \mathrm{g} \mathrm{mL}^{-1}$ $\mathrm{Bi}(\mathrm{III})$ solution was added.

\section{Optimization of experimental parameters}

In order to optimize the experimental conditions for the determination of $\mathrm{Pb}$ (II) and $\mathrm{Cd}(\mathrm{II})$, we investigated the effect of several parameters such as nitrogen purging time for extraction, TPAI concentration, deposition potential, anodic scan rate, and $\mathrm{Bi}(\mathrm{III})$ concentration. The effect of nitrogen purging time between 30 and $600 \mathrm{~s}$ on the stripping peak currents of $\mathrm{Pb}(\mathrm{II})$ was first investigated under the same conditions as those for Fig. 1. The peak currents were observed to gradually increase up to $120 \mathrm{~s}$ and then to remain constant between 120 and $600 \mathrm{~s}$. A purging time of $180 \mathrm{~s}$ was chosen as the most optimum time for the extraction of the metal iodide complexes into the $\mathrm{BMIM} \cdot \mathrm{PF}_{6}$ phase.

Next the effect of TPAI concentration on the stripping responses of $\mathrm{Pb}(\mathrm{II})$ and $\mathrm{Cd}(\mathrm{II})$ was investigated by varying the concentration between 0 and $0.20 \mathrm{~mol} \mathrm{~L}^{-1}$. The results shown in Fig. 2 indicate that the peak current of $\mathrm{Cd}(\mathrm{II})$ reached a maximum at $0.10 \mathrm{~mol} \mathrm{~L}^{-1}$ TPAI, whereas that of $\mathrm{Pb}$ (II) increased gradually with increasing concentrations of TPAI up to $0.20 \mathrm{~mol}$ $\mathrm{L}^{-1}$. The decrease of $\mathrm{Cd}(\mathrm{II})$ response in concentrations of TPAI higher than $0.10 \mathrm{~mol} \mathrm{~L}^{-1}$ is likely due to the formation of $\mathrm{CdI}_{6}{ }^{4-}$, followed by lower extraction of cadmium into the BMIM.PF phase. A TPAI concentration of $0.20 \mathrm{~mol} \mathrm{~L}^{-1}$ was chosen here.

The effect of deposition potential on the anodic responses of $\mathrm{Pb}$ (II) and $\mathrm{Cd}(\mathrm{II})$ was also investigated by varying the potential

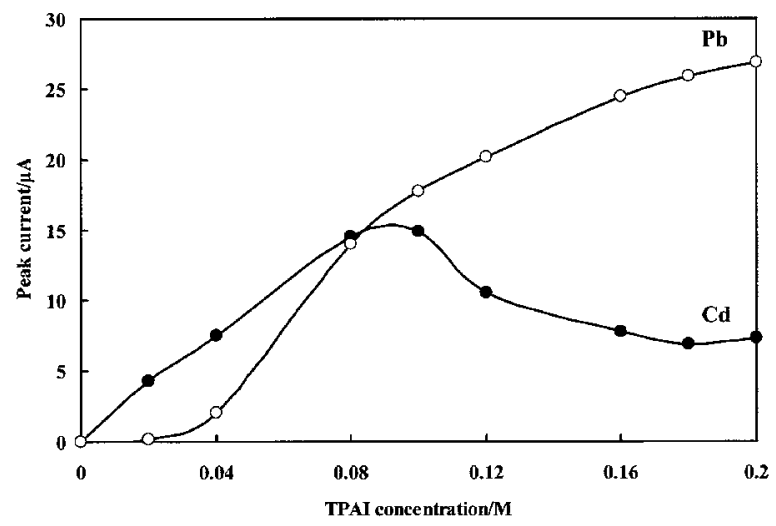

Fig. 2 Effect of TPAI concentration on DPASV peak-currents. Test solution, BMIM.PF 6 phases containing different concentrations of TPAI after the extraction equilibrium with the aqueous phase containing $1.0 \mu \mathrm{g} \mathrm{mL} L^{-1} \mathrm{~Pb}(\mathrm{II}), 1.0 \mu \mathrm{g} \mathrm{mL}-1 \mathrm{Cd}(\mathrm{II})$ and $5.0 \mu \mathrm{g} \mathrm{mL}^{-1}$ $\mathrm{Bi}(\mathrm{III})$; the other conditions were the same as for Fig. 1.

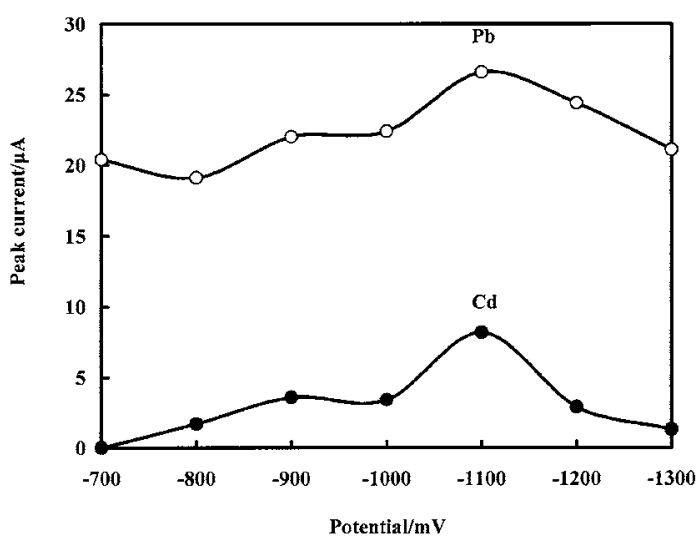

Fig. 3 Effect of deposition potential on DPASV peak-currents. Test solution, $0.2 \mathrm{~mol} \mathrm{~L}^{-1}$ TPAI solution in $\mathrm{BMIM}^{\mathrm{P}} \mathrm{PF}_{6}$ after extraction equilibrium with the mixed solution containing $1.0 \mu \mathrm{g} \mathrm{mL}^{-1} \mathrm{~Pb}(\mathrm{II})$, $1.0 \mu \mathrm{g} \mathrm{mL}{ }^{-1} \mathrm{Cd}(\mathrm{II})$ and $5.0 \mu \mathrm{g} \mathrm{mL}^{-1} \mathrm{Bi}(\mathrm{III})$; the other conditions were the same as for Fig. 1.

between -700 and $-1300 \mathrm{mV}$. From the results shown in Fig. 3, it can be seen that the responses of $\mathrm{Pb}(\mathrm{II})$ and $\mathrm{Cd}(\mathrm{II})$ reached maxima at $-1100 \mathrm{mV}$. At potentials more negative than -1200 $\mathrm{mV}$, the responses were decreased slightly due to hydrogen evolution on the electrode surface. The potential of $-1100 \mathrm{mV}$ was therefore selected as the optimum deposition potential for the determination of $\mathrm{Pb}(\mathrm{II})$ and $\mathrm{Cd}(\mathrm{II})$. As expected from earlier studies, the anodic responses of $\mathrm{Pb}(\mathrm{II})$ and $\mathrm{Cd}(\mathrm{II})$ were found to increase linearly when the deposition time increased over the range 0 to $600 \mathrm{~s}$. A deposition time of $180 \mathrm{~s}$ was used for further experiments because of a shorter analytical time and better reproducibility.

The effect of $\mathrm{Bi}(\mathrm{III})$ concentration on the anodic responses of $1.0 \mu \mathrm{g} \mathrm{mL}^{-1} \mathrm{~Pb}(\mathrm{II})$ and $\mathrm{Cd}(\mathrm{II})$ was investigated over the concentration range of 0 to $6.0 \mu \mathrm{g} \mathrm{mL}^{-1}$. As shown in Fig. 4, the peak currents were observed to increase gradually as the $\mathrm{Bi}$ (III) concentration increased. Higher $\mathrm{Bi}(\mathrm{III})$ concentrations between 5.0 and $6.0 \mu \mathrm{g} \mathrm{mL}^{-1}$ were found to make the anodic responses approximately constant. We also found that the Bi(III) concentration should be lowered to enhance the sensitivity of DPASV determination with an in-situ bismuth-film electrode. This is because the formation of a thick layer of bismuth on the 


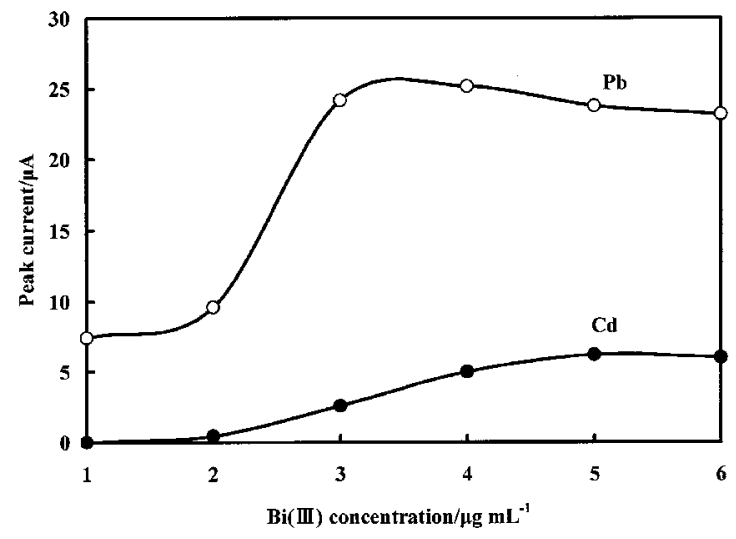

Fig. 4 Effect of $\mathrm{Bi}(\mathrm{III})$ concentration on DPASV peak-currents. Test solution, $0.2 \mathrm{~mol} \mathrm{~L}-1$ TPAI solution in BMIM.PF $\mathrm{PF}_{6}$ after extraction equilibrium with $1.0 \mu \mathrm{g} \mathrm{mL}{ }^{-1} \mathrm{~Pb}$ (II) and $1.0 \mu \mathrm{g} \mathrm{mL}-1 \mathrm{Cd}(\mathrm{II})$ at different concentrations of $\mathrm{Bi}(\mathrm{III})$; the other conditions were the same as for Fig. 1.

electrode surface restricts the anodic dissolution of target metal ions for analysis. In this study, $5.0 \mu \mathrm{g} \mathrm{mL} \mathrm{m}^{-1} \mathrm{Bi}(\mathrm{III})$ was added to the test solutions.

The effect of scan rate on the anodic responses was investigated in the range of 20 to $200 \mathrm{mV} \mathrm{s}^{-1}$. An anodic scan rate of $100 \mathrm{mV} \mathrm{s}^{-1}$ was used because the highest peak currents were found to obtain for $\mathrm{Pb}(\mathrm{II})$ and $\mathrm{Cd}(\mathrm{II})$. Outside the scan rate, the peak currents significantly decreased.

\section{Calibration curves and detection limits}

At the optimized parameters, linear calibration curves for the DPASV determination of $\mathrm{Pb}(\mathrm{II})$ and $\mathrm{Cd}(\mathrm{II})$ were constructed over the concentration range of $0.01-0.5$ and $0.05-1.0 \mu \mathrm{g}$ $\mathrm{mL}^{-1}$, respectively (Fig. 5). At $\mathrm{Pb}(\mathrm{II})$ concentrations higher than $0.50 \mu \mathrm{g} \mathrm{mL} \mathrm{mL}^{-1}$, the curve gradually deviated from the linear relationship. The linear regression analysis indicated that these curves were expressed by $i_{\mathrm{p}}(\mu \mathrm{A})=0.7+31.4\left[\mathrm{~Pb}\left(\mu \mathrm{g} \mathrm{mL} L^{-1}\right)\right]$ and $i_{\mathrm{p}}(\mu \mathrm{A})=-0.3+8.88[\mathrm{Cd}(\mu \mathrm{g} \mathrm{mL}-1)]$ with correlation coefficients higher than 0.995 . The intercepts are derived from the different slopes of the calibration curves obtained at lower metal concentrations. The relative standard deviations $(n=10)$ at $0.20 \mu \mathrm{g} \mathrm{mL}^{-1} \mathrm{~Pb}(\mathrm{II})$ and $\mathrm{Cd}(\mathrm{II})$ were 3.2 and $5.1 \%$, respectively. The detection limits $(S / N=3)$ were estimated to be 0.005 and $0.03 \mu \mathrm{g} \mathrm{mL} \mathrm{m}^{-1}$ for $\mathrm{Pb}(\mathrm{II})$ and $\mathrm{Cd}(\mathrm{II})$, respectively. A detection limit of $0.001 \mu \mathrm{g} \mathrm{mL}-1 \mathrm{~Pb}$ (II) was obtained under the following experimental conditions: $0.2 \mathrm{~mol} \mathrm{~L}^{-1} \mathrm{TPAI} ; 1.0 \mathrm{~mol} \mathrm{~L}^{-1}$ potassium nitrate; a volume ratio $\left(V_{\text {aq }} / V_{\mathrm{BMIM}_{\mathrm{PF}}}\right)$ of $2.0 ; 300 \mathrm{~s}$ deposition time. In the determination of $\mathrm{Pb}(\mathrm{II})$, the sensitivity of the proposed method is comparable to that obtained with in-situ bismuth-film electrode in aqueous media. The improved sensitivity and selectivity in DPASV are expected by the combination of solvent extraction using BMIM.PF . The proposed method would provide a promising tool for some purposes of analytical application, e.g. analyses of industrial and environmental materials.

\section{Interference}

The effect of foreign ions on the DPASV determination of 0.2 $\mu \mathrm{g} \mathrm{mL} \mathrm{L}^{-1} \mathrm{~Pb}(\mathrm{II})$ was investigated over a range of concentrations. The presence of $\mathrm{Al}(\mathrm{III}), \mathrm{Ca}(\mathrm{II}), \mathrm{Mg}(\mathrm{II})$, and $\mathrm{Ni}(\mathrm{II})$ up to $25.0 \mu \mathrm{g}$ $\mathrm{mL}^{-1}$ was tolerable within $\pm 10 \%$ error. There was no interference from $\mathrm{Zn}(\mathrm{II}), \mathrm{Co}(\mathrm{II}), \mathrm{Sb}(\mathrm{III}), \mathrm{Co}(\mathrm{II}), \mathrm{W}(\mathrm{VI}), \mathrm{Mo}(\mathrm{VI})$, $\mathrm{V}(\mathrm{V})$ at 10 -fold amounts excess over $\mathrm{Pb}(\mathrm{II})$, and from $\mathrm{Fe}(\mathrm{III})$ at a 20 -fold amount. No interference was also observed for $\mathrm{Na}(\mathrm{I})$,

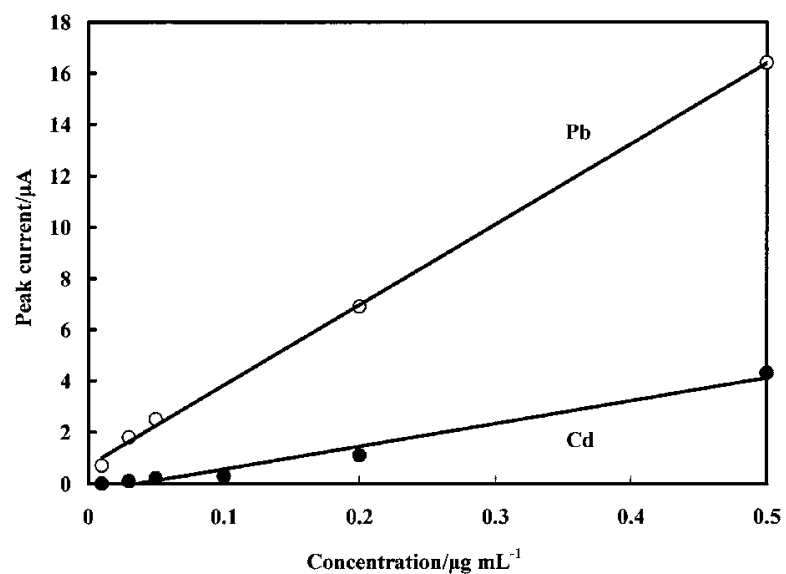

Fig. 5 Calibration curves for the DPASV determination of $\mathrm{Pb}$ (II) and $\mathrm{Cd}(\mathrm{II})$. Aqueous phase, $2.0 \mathrm{~mL}$ of the mixed solution containing $0.1 \mathrm{~mol} \mathrm{~L}^{-1}$ acetate buffer $(\mathrm{pH} 4.5), 0.5 \mathrm{~mol} \mathrm{~L}^{-1}$ potassium nitrate and $5.0 \mu \mathrm{g} \mathrm{mL} \mathrm{m}^{-1} \mathrm{Bi}(\mathrm{III})$; organic phase, $2.0 \mathrm{~mL}$ of $0.2 \mathrm{~mol} \mathrm{~L}{ }^{-1} \mathrm{TPAI}$ solution in BMIM.PF ; the other conditions were the same as for Fig. 1.

$\mathrm{H}_{2} \mathrm{PO}_{4}^{-}, \mathrm{NH}_{4}{ }^{+}$at 100 -fold amounts, and for $\mathrm{NO}_{3}{ }^{-}$and $\mathrm{SO}_{4}{ }^{2-}$ at 1000 -fold amounts. The presence of most organic surface-active compounds at high concentrations should be avoided for real sample analysis.

\section{References}

1. P. T. Kissinger and T. H. Ridgway, in "Laboratory Techniques in Electroanalytical Chemistry", ed. P. T. Kissinger and W. R. Heineman, 1996, Marcel Dekker, New York, 158.

2. J. Wang, "Stripping Analysis", 1985, VCH, Florida.

3. V. Stara and M. Kopanica, Anal, Chim. Acta, 1988, 208, 231.

4. P. Breyer and B. P. Gilbert, Anal. Chim. Acta, 1987, 201, 33.

5. S. B. Adeloju, D. Jagner, and L. Renman, Anal. Chim. Acta, 1997, 338, 199.

6. E. A. McGaw and G. M. Swain, Anal. Chim. Acta, 2006 , 576,180

7. B. Lange and C. M. G. van den Berg, Anal. Chim. Acta, 2000, $418,33$.

8. G. Mattsson, L. Nyholm, and A. Olin, J. Electroanal. Chem., 1994, 379, 49 .

9. J. Wang and J. Lu, Anal. Chim. Acta, 1993, 274, 219.

10. P. Salaun, B. Planer-Friedrich, and C. M. G. van den Berg, Anal. Chim. Acta, 2007, 585, 312.

11. M. C. Santos and S. A. S. Machado, J. Electroanal. Chem., 2004, 567, 203

12. P. Sonthalia, E. A. McGaw, Y. Show, and G. M. Swain, Anal. Chim. Acta, 2004, 522, 35.

13. G. Li, Z. Ji, and K. Wu, Anal. Chim. Acta, 2006, 577, 178.

14. J. Wang and J. Lu, Electrochem. Commun., 2000, 2, 390.

15. A. Economou, Trends Anal. Chem., 2005, 24, 334.

16. J. Wang, Electroanalysis, 2005, 17, 1341.

17. R. T. Kachoosangi, C. E. Banks, X. Ji, and R. G. Compton, Anal. Sci., 2007, 23, 283.

18. J. Long and Y. Nagaosa, Anal. Chim. Acta, 2007, 593, 1 .

19. J. Long and Y. Nagaosa, Anal. Sci., 2007, 23, 1343.

20. J. Wang, J. Lu, S. B. Hocevar, and B. Ogorevc, Elecroanalysis, 2001, 13, 13. 
21. C. Prior and G. S. Walker, Electroanalysis, 2006, 18, 823.

22. J. Long and Y. Nagaosa, Int. J. Environ. Anal. Chem., 2008, $88,51$.

23. G. Kefala, A. Economou, and A. Voulgaropoulos, Electroanalysis, 2006, 18, 223.

24. M. Korolczuk, M. Grabarczyk, and A. Moroziewicz, Electroanalysis, 2005, 17, 120.

25. Y. Nagaosa and T. Yamada, Talanta, 1984, 31, 371.

26. Y. Nagaosa and S. Sana, Bunseki Kagaku, 1992, 33, 22.

27. Y. Nagaosa and K. Horita, Mikrochim. Acta, 1992, 108, 151.

28. Y. Nagaosa, K. Horita, and S. Nishimoto, Fresenius J. Anal. Chem., 1984, 342, 698.

29. H. Zhao, S. Xia, and P. Ma, J. Chem. Technol. Biotechnol., 2005, 80, 1089.
30. S. Pandey, Anal. Chim. Acta, 2006, 556, 38.

31. J. Liu, J. A. Jonsson, and G. Jiang, Trends Anal. Chem., $\mathbf{2 0 0 5}, 24,20$.

32. J. Zhang and A. M. Bond, Anal. Chem., 2003, 75, 2694.

33. M. C. Buzzeo, R. G. Evans, and R. G. Compton, ChemPhysChem, 2004, 5, 1107.

34. L. Kavan, L. Dunsch, and H. Kataura, Carbon, 2004, 42, 1011.

35. F. Y. Su, J. F. Huang, and I. W. Sun, J. Elecrochem. Soc., 2004, 151, 811.

36. J. Jia, L. Cao, Z. Wang, and T. Wang, Electroanalysis, 2008, 20,542 .

37. M. Yamagata, N. Tachikawa, Y. Katayama, and T. Miura, Electrochim. Acta, 2007, 52, 3317. 